Sebastian Bednarowicz

Adam Mickiewicz University in Poznań

\title{
Syriaco-Slavica. What did the Syriac medieval writers know about the Slavs
}

In one of the Old Church Slavonic documents, the Life of Constantine, the Apostle to the Slavs, appears an interesting mention about a man who Cyril-Constantine met in the Crimean Chersonesus and who had the Gospels and Psalter written in "rosky" or "rusky" letters. The question, "what did the author of the Life mean writing rosky/rusky," has been discussed by scholars for many years but there has not been any satisfactory explanation as yet. Usually, three attempts to answer it have been offered. ${ }^{1}$ The first attempt claims that it was a writing system of the Russian Slavs, the second one perceives the runic letters of the Goths that inhabited the Crimean Peninsula at least till the $16^{\text {th }}$ century in the word "rosky/rusky." Nevertheless, the third solution seems to be very convincing, namely, some scholars think that the term "rosky/rusky" is a mistake of the copyist and originally it was written "sursky", which means Syriac. This elucidation gives an impression to be reasonable, especially because of the later information that Constantine learnt very quickly to differentiate the letters of vowels from those of consonants. This distinction could suggest that the Psalter was written in a Semitic language (e.g., Syriac). If this explanation is true, the Life of Constantine can be treated as a testimony of one of the oldest Syriac-Slavonian contacts.

The origins of the Slavonian peoples disappear in the darkness of history. As yet there have been no satisfactory explanations where their homeland had been before they, at the beginning of the $6^{\text {th }}$ century, crossed the Danube and started their raids into the Balkans. Our information about the early Slavs is vestigial and grounded only on some linguistic (onomastica and hydronimica) data. These are, however, acknowledged by many scholars to be sufficient

\footnotetext{
${ }^{1}$ See, H. Birnbaum, Some Remaining Puzzles in Cyrillo-Methodian Studies, "Slovo" (47-49) 1997-1999, pp. 9-15.
} 
to recognize the region of Volynia, the middle Dnepr and the regions southward from Kiev as the primitive Slavonian habitat. According to them the Slavs should have lived there already in the third millennium B.C. and then began spreading in the west, northeast and south. ${ }^{2}$ Nevertheless, the period before 500 A.D. has to be still treated as a prehistory of the Slavonian peoples. ${ }^{3}$

The Slavonian raids and settlements in the Balkan provinces of the Byzantine Empire coincided with the blossom of the Syriac literature. At that time a bulk of, both native and translated from Greek and other languages, Syriac works came into being. So if some mention about the Syriac speaking Christians appears in one of the first monuments of the Slavic literature, the question arises whether the medieval Syrians had also some knowledge of the Slavonian tribes. This is the main purpose of this paper. At first, we will try to trace the works of three Syriac historians (John of Asia, Michael the Great and Bar Hebraeus), and then the Syriac apocrypha, aiming at finding some information about the Slavs.

\section{Historical works}

The first veritable accounts about the Slavs we possess come from the works of the Byzantine chroniclers: Procopius (ca. 500-562) and Jordanes ( $6^{\text {th }}$ century), who wrote about two Slavonian tribes, as well as the Antes and Sclavenes that were ravaging the Balkan Peninsula in the $6^{\text {th }}$ century. Nevertheless, they also give some data about their homelands. For instance, in his Gethica $(\mathrm{V}, 35)$ Jordanes relates, "The abode of the Sclaveni extends from the city Noviodunum and the lake called Mursianus to the Danaster, and northward as far as the Vistula. They have swamps and forests for their cities. The Antes, who are the bravest of these peoples dwelling in the curve of the sea of Pontus, spread from the Danaster to the Danaper, rivers that are many days' journey apart"4

Although the Byzantine authors are the main source of our knowledge about the early Slavs we should not forget that we owe some data only to Syriac writers (even from the $6^{\text {th }}$ century).

\section{John of Asia}

The first Syriac historian writing about the Slavs, namely about the tribe of the Sclavenes, was John of Asia (d. 589). Although he was born in the Mesopotamian Amid, he spent a great part of his life in Constantinople. Jacob

${ }^{2}$ See, Z. Goląb, O pochodzeniu Stowian w świetle faktów językowych, Kraków 2004, pp. 363-367.

${ }^{3}$ See, J. Reczek, Polszczyzna i inne języki w perspektywie porównawczej, Wrocław-WarszawaKraków 1991, p. 11.

${ }^{4}$ The Gothic History of Jordanes, in English version with an introduction and a commentary by C. C. Mierow, London 1915, pp. 59-60. 
Burde'ana ordained him bishop of Ephesus but John, because of the strong anti-Monophysitist opposition during the reign of Justinianius, could never take over the bishopric throne of this city. He lived in imperial Constantinople where he was one of the leaders of the anti-Chalcedonian party.

The main literary work of John is The Ecclesiastical History ${ }^{5}$ divided into three parts. Unfortunately, the first two parts were lost. In the third one, however, he as the first Syriac writer, informs about the invasion of the Slavonian hordes on the Balkan parts of the Empire. John mentions the Slaves in following excerpts of his work,

1) in Book III (chapter 25) he writes that after the death of Justin II (i.e. after 578) the barbarians "pressed upon him [id est the Empire] with still greater violence, especially the accursed tribes of the Slavonians (Sclavenes), and those who, from their long hair, are called Avars."

2) in Book V (chapter 19) John writes about the wars with the Avars conducted by Emperor Maurice (582-602). The Slavonians were only mentioned there.

3) Book VI (chapter 25) contains a detailed description of the Slavonian raid into Greece, Thessalia and Thracia, "That same year, being the third after the death of king Justin, was famous also for the invasion of an accursed people, called Slavonians, who overran the whole of Greece, and the country of the Thessalonians, and all Thrace, and captured the cities, and took numerous forts, and devastated and burnt, and reduced the people to slavery, and made themselves masters of the whole country, and settled in it by main force, and dwelt in it as though it had been their own without fear. And four years have now elapsed, and still, because the king is engaged in the war with the Persians, and has sent all his forces to the East, they live at their ease in the land, and dwell in it, and spread themselves far and wide as far as God permits them, and ravage and burn and take captive. And to such an extent do they carry their ravages that they have even ridden up to the outer wall of the city, and driven away all the king's herds of horses, many thousands in number, and whatever else they could find. And even to this day, being the year 895 (A. D. 584), they still encamp and dwell there, and live in peace in the Roman territories, free from anxiety and fear, and lead captive and slay and burn: and they have grown rich in gold and silver, and herds of horses, and arms, and have learnt to fight better than the Romans, though at first they were but rude savages, who did not venture to show themselves outside the woods and the coverts of the trees; and as for arms, they did not even know what they were, with the exception of two or three javelins or darts." 7

${ }^{5}$ The Third Part of the Ecclesiastical History of John, Bishop of Ephesus, now first translated from the original Syriac by R. P. Smith, Oxford 1860.

${ }^{6}$ Ibid., p. 207.

${ }^{7}$ Ibid., pp. 432-433. 


\section{Michael the Syrian}

Michael the Syrian (Michael the Great or the Elder) was one of the most important writers of the late Classical period of the Syriac literature. He lived in the years 1126-1199 and from 1166 he was a patriarch of Syrian Orthodox Church. As a leader of West Syrian Christians he endeavored to come into contact with both Byzantine and Latin Churches. His position should be high even apart from his confessional community. In 1179 he was even invited to take part in the Lateran Council. Among his dogmatic, biographic, polemic and liturgical works the special place takes Universal Chronicle, presenting history of the world from creation up to the year 1194/1195. In his chronicle Michael used many sources including those of non-Christian origin and it is worth stressing that he did not only cite them but also tried to examine their reliability, which made his chronicle very valuable as a historical work.

This paper is based on the French translation of Michael's chronicle, made by J.B. Chabot ${ }^{8}$ and the Syriac text edited by Kiraz. ${ }^{9}$ The Slavs appeared in following books,

Book IX, XXIII: "Ensuite vinrent les armées des Huns et des Esclavons, qui assiégèrent la ville impériale. Ils percèrent le mur extérieur; ils pillèrent et brûlèrent tous les faux-bourgs, firent captifs tous ceux qu'ils y trouvèrent, et s'en allèrent. - Ils revinrent une seconde et une troisième fois. Alors, les Romains prévalurent contre eux; ils les détruisirent et les tuèrent tous dans le combat. On ne vit plus nulle part le petit nombre de ceux qui s'étaient enfuis. - Et ainsi ils furent délivrés d'eux."10

Book X, XVIII: "Puis, les peuples occidentaux des Esclavons et d'autres qu'on appelait Longobardes, étant tous passés sous la domination de Khâgan, roi des Avares, ils jetèrent un autre pont sur le Danube. En l'an 3 de Tiberius, le peuple maudit des Esclavons sortit et parcourut l'Hellade, la région des Thessaloniens, la Thrace, qu'ils ravagèrent et incendièrent. Ils envahirent la région et s'y répandirent, lis s'emparèrent des troupes de chevaux de l'empereur : ces hommes barbares qui (jusqu'alors) ne pouvaient se montrer hors des forêts et des lieux couverts, et ne savaient pas ce que c'est qu'une armure, en dehors de deux ou trois petites lances ou javelots, apprirent l'art de la guerre. Ils dominèrent pendant longtemps dans les pays des Romains." 11

${ }^{8}$ Chronique de Michel le Syrien, Patriarche Jacobite d'Antioche (1166-1199), éditée pour la première fois et traduite en français par J.-B. Chabot, vol. 1-4, Paris 1899-1910.

${ }^{9}$ Texts and Translations of the Chronicle of Michael the Great. Syriac Original, Arabic Garshuni Version, and Armenian Epitome with Translations into French, vol. 1: The Edessa-Aleppo Syriac Codex of the Chronicle of Michael the Great, ed. by G. Yuhanna Ibrahim, New Jersey 2009.

${ }^{10}$ Chronique de Michel le Syrien, Patriarche Jacobite d'Antioche (1166-1199), op. cit., vol. 2 , p. 269.

${ }^{11}$ Ibid., p. 346. 
Book X, XX: “A cette époque, tandis que les armées romaines se portaient en Perse, les peuples barbares des Avares et des Esclavons ravageaient les pays des Romains; et tandis que les Romains combattaient en Perse, le marzban Adarmôn envahit de nouveau le territoire des Romains et parvint jusqu'à Edesse."12

Book X, XXI: "La cruelle inimitié entre les Romains et les Perses s'était prolongée pendant vingt ans. Les Romains furent attaqués de nouveau par les peuples des maudits barbares à chevelure inculte, qu'on appelle Avares qui s'ébranlèrent et s'avancèrent des extrémités de l'Orient, et aussi par le peuple occidental des Esclavons et par d'autres qu'on appelait Longobards. Ceux-ci étaient aussi sous la domination de Khâgan, roi des Avares.

Ils allèrent assiéger deux villes des Romains, et d'autres forteresses. Ils dirent aux habitants; «Sortez; semez et moissonnez; nous prendrons de vous seulement la moitié de l'impôt». - Si l'empereur n'avait fait faire un grand fossé en dehors d'Andrinople, ils tournaient déjà leurs regards vers la ville impériale. L'empereur et ses armées tremblèrent et furent pris de crainte en face des Barbares. Une armée fut envoyée et établie au mur extérieur, qui est à plus de soixante milles de (la capitale). Il enrôla, contraint par la nécessité, une partie des clercs de l'Église. Les gardes du corps furent vivement envoyés de tous côtés pour choisir des recrues. Ceux-ci étant partis, causèrent beaucoup de maux. Ils enlevèrent les enfants aux parents et ils ruinèrent eux-mêmes les pays. Ils imposaient partout aux habitants le tribut (?) des chevaux, des bœufs et même des poules.

Le peuple des Esclavons fit des captifs en tous lieux; (ils enlevèrent les objets) du culte des églises et de grands ciborium sur des chariots solides, par exemple celui de l'église de Corinthe, que (leur roi) fit fixer et dresser au lieu de tente, et sous lequel il siégeait. Alors les Romains prirent à gages le peuple des Antes qui se jetèrent sur le pays des Esclavons dont ils s'emparèrent et qu'ils pillèrent. Ils en enlevèrent les richesses et ils l'incendièrent. Leur pays était à l'ouest du fleuve appelé Danube.

Quand les Esclavons apprirent que leur pays était dévasté, ils rugirent comme le lion sur sa proie; ils se réunirent par milliers, et se mirent à piller sans fin. Ils ne purent s'avancer jusqu'à assiéger la ville impériale. Ils se tournèrent vers la ville d'Anchiales et vers les Thermes de cet endroit. Beaucoup d'entre eux avaient été massacrés par l'armée qui s'y trouvait. A la fin, ils renversèrent les murs; ils trouvèrent là les vêtements de pourpre qu'Anastasia, femme de Tiberius, avait donnés en vœu à l'église, lorsqu'elle se rendait aux Thermes. Khâgan s'en revêtit en disant : «Que l'empereur des Romains le veuille ou non, voici que la royauté m'a été donnée », - Bientôt après il fut effrayé par la nouvelle que le peuple des Turcs le poursuivait. Ils se retirèrent à Sirmium, craignant que

\footnotetext{
${ }^{12}$ Ibid., p. 353.
} 
(les Turcs) ne pillassent les habitants et toutes ses richesses. (Mauricius) ayant

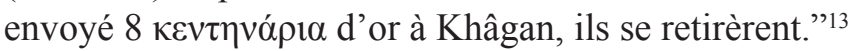

Book XI, XV: "Justinianus, empereur des Romains, qui avait un orgueil insolent, ne permit pas que Cypre fût aux Romains et aux Taiyayê; il en fit enlever les habitants, en la [7e] année de son règne. En apprenant cela, Abd el-Malik lui reprocha vivement d'avoir rompu la paix et de n'avoir pas patienté, jusqu'à la fin des (dix) années. Cest pourquoi, Mohammed, émir de Djézireh, envahit le Beit Roumayê. Les Romains lui livrèrent bataille à côté de Césarée de Cappadoce. Les Esclavons prirent le parti des Taiyayê et s'en allèrent avec eux en Syrie, au nombre d'environ 7 mille. Ceux-ci les établirent à Antioche et à Cyrrhus, leur donnèrent des femmes et leur partagèrent le tribut et les provisions." 14

Book XI, XVI: "Quand les Esclavons se révoltèrent contre les Romains, comme Leontius ne se préoccupait pas d'eux, ils pillaient et dévastaient le pays des Romains; alors Apsimaros marcha contre eux, les vainquit et les soumit."15

\section{Bar Hebraeus}

Gregorios Bar Ebraya, born in 1226, is considered to be one of the last eminent figures of the Syriac classical literature. At the age of twenty he was ordained bishop and twenty years later he was elected a maphrian. He died in 1286. Bar Hebraeus was a famous historian, theologian and linguist. He wrote a chronicle of the world, divided into eleven dynasties. This work was very popular in respect of a large number of historical data it contained. Bar Hebraeus based his chronicle on the earlier Greek, Syriac and Arabic historians.

Bar Hebraeus' chronicle was published several times. We use the edition of Paul Bedjan $(1898)^{16}$ and the English translation of E. A. Wallis Budge (1932) ${ }^{17}$ This great Syriac scholar wrote about the Slaves in the following excerpts:

Dynasty VIII: "And after these things the armies of the HUNS and the ASKLABE came and encamped about the royal city, and they broke down the outer walls, and plundered and burnt all the colonnades; and they seized everything which they found and departed. And they came again, a second and a third time, and then the RHOMAYE gained the mastery and destroyed

${ }^{13}$ Ibid., pp. 361-363.

${ }^{14}$ Ibid., p. 470.

${ }^{15}$ Ibid., p. 473.

${ }^{16}$ Gregorii Barhebraei Chronicon syriacum, e codd. mss. emendatum ac punctis vocalibus adnotationibusque locupletatum [a P. Bedjan], Paris 1890.

${ }^{17}$ The Chronography of Gregory Abu'l Faraj, the Son of Aaron, the Hebrew Physician, Commonly Known as Bar Hebraeus: Being the First Part of His Political History of the World, translated from the Syriac by E. A. Wallis Budge, vol. 2, London 1932. 
them in the war [which followed]. The few of them who escaped never again appeared in the place." 18

Dynasty IX: "At this time when the army of the RHOMAYE was marching to PERSIA with MAURICIUS CAESAR, the barbarian peoples of ABHARIS and ASKLABHONE and LONGOBARDY, who were subject to the KHAKAN, laid waste the countries of the RHOMAYE." 19 "And in the fourth year of his reign there broke forth and went out from the EAST a hateful people from ABARIS whose hair was plaited, and from the WEST also came the SLAVS and the LONGOBARDS. And they came under the subjugation of the KHAKAN, king of the KAZARAYE, and they captured two cities from the RHOMAYE and many of [their] fortresses. And if it had not been for the great ditch which the king had made outside ADRIANOPLE, they would have set their faces towards CONSTANTINOPLE. Then the RHOMAYE killed the people of ANTIO (ANTU), and they fell upon ASKLABHUNYA and captured it and looted it. When the ASKLABHONE heard this they made a great war (i.e. raid) in the country of the RHOMAYE and came back." ${ }^{20}$

Dynasty X: "Then JUSTINIANUS waxing proud, transgressed [his] oaths, and he broke the peace before it was fulfilled, and he sent and made captives the ARABS who were in CYPRUS. Because of this MAHAMMAD, the Amir of the island of KARDU, went to CAPPADOCIA, and the RHOMAYE and the ASKLABE (SLAVS) attacked him in battle, and the RHOMAYE were defeated near CESARAEA. And the ASKLABE (SLAVS) made friends with the ARABS, and about seven thousand of them went out with them to SYRIA. And they settled them in ANTIOCH and in KUROS, and gave them women and provisions (rations?)." 21

"This TIBERIUS subjugated again the SLAVS who had rebelled against the RHOMAYE."22

"And after him his brother CONSTANTINUS reigned four years. And at the beginning of his kingdom SIMIAN, the chief of the BULGARIANS and SCLAVS, came against CONSTANTINOPLE, and he destroyed many villages. And he afflicted the city also, and he made against it a great ditch [which reached] from BELAKERNE to the gate which is called 'Golden.' And the king of the RHOMAYE sent [a dispatch] to him, saying, 'Since we are all Christians, and the children of one baptism, why do such dissentions as these exist between us?' And as SIMION refused to be propitiated (or, reconciled), king CONSTANTINUS collected the Arab prisoners who

\footnotetext{
${ }^{18}$ Ibid., p. 76 [Bedjan's edition: 82].

${ }^{19}$ Ibid., p. 83 [Bedjan's edition: 89-90].

${ }^{20}$ Ibid., p. 84 [Bedjan's edition: 90].

${ }^{21}$ Ibid., pp. 103-104 [Bedjan's edition: 111-112]

${ }^{22}$ Ibid., p. 104 [Bedjan's edition: 112].
} 
were in CONSTANTINOPLE, and he promised them that if they would help the RHOMAYE to victory [over] the BULGARIANS he would set them free. And having sworn to the king oaths [that they would do so], weapons of war were given to them. And the RHOMAYE went forth with the ARABS with one purpose, and they defeated the SCLAVS, and killed many of them, and the rest fled. The king (CONSTANTINUS), however, went back on his promise, and he took away from the ARABS their weapons, and threw iron fetters on them again, and scattered them throughout his provinces, for he was afraid lest they should set up a chief for themselves. The history of the blessed MAR MICHAEL, which dealeth with the war of the RHOMAYE with the ARABS, [testifieth] to this, and he introduceth it in the Arabic manuscripts [which describe] the war with the SCLAVS, and it is correct. For during the war with the ARABS the RHOMAYE would never have believed it [safe] to release the Arab prisoners from their bonds, and to put weapons of war into their hands." ${ }^{23}$

"After MUTHAKI, MUSTAKFI, the son of MUKTAFI, [ruled] one year and four months. And during the year in which he reigned, various peoples, the ALANAYE, and the ASLABHAYE (SCLAVS), and the LAGZAYE, went forth and came to ADHORBIJAN, and they captured the city, the name of which was BARDA'AH, and they killed therein about twenty thousand men and departed." ${ }^{\prime 24}$

"And in the year thirteen hundred and forty-one of the GREEKS (A.D. 1030), which is the year four hundred and twenty-one of the ARABS (A.D. 1030), an army of the RHOMAYE went forth from ANTIOCH and encamped against ALEPPO. And the small group of ARABS which was in ALEPPO engaged the RHOMAYE and defeated them, and they killed many of them; and the ARABS took from the RHOMAYE many horses and weapons of war. For the kings who were before ROMANUS, since they were relieved from the persecution of the believers (i.e. Muslims), were prosperous everywhere. But this king began to persecute [the Christians], and he cast forth into exile the holy Patriarch MAR ABDUN and the bishop, and he reversed the ancient use and wont; and the Lord likewise began to break the deceitful RHOMAYE before their enemies. And in that year, when ROMANUS the king heard that the RHOMAYE were broken at ALEPPO, he collected a mighty army, more than one hundred thousand men, and came to ANTIOCH; and from there he set out to come to ALEPPO. And since two nobles of the ASKLABE (SCLAVS) and the army that was with them were [marching] a little in advance of the army of the RHOMAYE, they encountered about one hundred MA'DAYE horsemen and a thousand foot soldiers, and the SCLAVS were broken, and turned their faces [in flight]. And they made a report to the RHOMAYE, saying, 'Behold,

\footnotetext{
${ }^{23}$ Ibid., p. 152 [Bedjan's edition: 167].

${ }^{24}$ Ibid., p. 163 [Bedjan's edition: 180].
} 
innumerable soldiers, EGYPTIANS and MA'DAYE, are coming.' And fear fell upon the RHOMAYE, and with the greatest difficulty ROMANUS the king and his troops, one by one, each on his horse, fled to ANTIOCH without fighting and without [striking] a blow. And the ARABS overtook them, and they captured from the RHOMAYE seventy camels with their loads of zuze and dinars, and vessels of gold and silver, and bales of rich stuffs, and such a large number of mules that a Tarka mule was sold in ALEPPO for two dinars. It is said that ROMANUS himself was not able to save one tent or a cup from which he could drink water." ${ }^{25}$

"And in this year a great army of SCLAVS, that is to say RUSSIANS, came against the royal city by sea and by 1 and. And God helped the RHOMAYE, and they set fire to their ships and burned them on the sea, and the greater number of them were burned and sunk. And similarly they made prisoners of many of those who had come by land, and they cut off their right hands; and the RHOMAYE obtained a great victory." 26

"And at this time TUSHI, the eldest son of CHINGIZ KHAN, died. And he left seven grown-up sons who were: TAMSHAL, HARDU, BATU, SIBARAN, TANGUTH, BARAKAH, and BARKAJAR. And from among these the Khan selected BATU, and to him he handed over the northern countries of the SLAVS, and the GERMANS, and the RUSSIANS, and the BULGARIANS. And his seat was on the great river which is called ITIL (i.e. the VOLGA). And BATU, whilst going on the northern road from the country of the IBERIANS to the countries of the BULGARIANS and SCYTHIANS, destroyed their populations by the edge of the sword, and blotted out their kingdoms. And because the command of the Khan had gone forth in this wise: [The troops] shall cut off the right ear of every BULGARIAN and RUSSIAN who is killed, when they counted the ears, two hundred and seventy thousand ears were found with the TATARS." ${ }^{27}$

\section{Remarks on the Syriac historians' views of the Slavs}

Syriac Ethnonyms of the Slavs

The Syriac writers used different terms to name the Slavs. John of Asia called them Asqūlinnē or Asqlāwinne. ${ }^{28}$ Michael used the terms Asqlābē, Asqūlìnē, Asqlāwīnē, Asqlāwnāye $\bar{e}^{29}$ and Bar Hebraeus: Asqlābōnē, Asqlābē, Asqlābāyē. This variety of ethnonymic forms reflects the different sources that were

\footnotetext{
${ }^{25}$ Ibid., pp. 191-192 [Bedjan's edition: 213-214].

${ }^{26}$ Ibid., p. 203 [Bedjan's edition: 227].

${ }^{27}$ Ibid., p. 398 [Bedjan's edition: 465].

${ }^{28}$ R. Payne Smith, Thesausus Syriacus, Oxonii 1879, p. 319.

${ }^{29}$ The Edessa-Aleppo Syriac Codex of the Chronicle of Michael the Great, ed. G. A. Kiraz and Gregorios Yuhanna Ibrahim, New Jersey 2009. The name "Slavs" appears on pp. 327, 375, $382,383,449$ and 450 .
} 
employed by these Syriac authors when they were composing their works. The bulk of them is of Byzantine provenience.

For the Greek writers of the $6^{\text {th }}$ century the Slavs were a totally new group of barbarian tribes. They had no name to call them and at first they used the term $\Sigma \kappa \lambda \alpha \beta \eta v o$ being probably an appellation of one of the Slavonian tribes that together with the Avars devastated the west provinces of the Byzantine Empire. That is why John of Asia named them Asqlāwìne or Asqūlinnē (beta in Byzantine Greek was pronounced as v). Nevertheless, as early as in the $6^{\text {th }}$ century the new shorter name $(\Sigma \kappa \lambda \alpha \beta o t)$ for the Slavonian newcomers was employed. It originated in Constantinople and was used for the first time by John Malalas (d. 578), a Syrian chronicler who lived in the capital city. This form became a common name for all Slavonian peoples very early and owing to Martin of Braga (d. 580), who returning from the Holy Land travelled through Constantinople, as the Sclavi came to the Latin Europe. ${ }^{30}$

In the texts of the Syriac historians the older name of the Slavs appears only if it refers to the events of the sixth century. Describing the later ages they used only the form derived from $\Sigma \kappa \lambda \alpha \beta$ or. However, there is one exception to this rule. Namely, when Michael and Bar Hebraeus were writing about the siege of Constantinople by the Huns and Slavs, they both employed the name Asqlābe though that attack took place in the year 559, therefore, it was even earlier than the events described by John of Asia. The explanation of this inconsequence seems to be very simple. The main source of information about the siege of the Imperial City by the Huns and Slavs was the chronicle of John Malalas' who, as we have already mentioned, used the short term. In the eighteenth book of his work he wrote (chapter 129): "In the month of March of the $7^{\text {th }}$ indiction the Huns and the Slavs [ $\Sigma \kappa \lambda \alpha \beta o r$, S.B.] made an attack on Thrace. They killed many in battle and took some captives, including the magister militium Sergius, the son of Bacchus, and Edermas, major domo of Kalopodios, making them prisoners. They found parts of the wall of Constantinople had collapsed and, entering there, they raided as far as St Stratonikos. Everyone fled with their possessions into the city. On being informed of this, the emperor conscripted many and sent them to the Long Wall. They engaged the enemy there and many Romans, especially scholarii, were killed. Then the emperor ordered that the silver kibouria and silver altar tables that were outside the city be removed while the scholae, the protectores, the numeri and the whole senate guarded all the gates of the Theodosian Wall. When the emperor saw that the barbarians were staying put, he ordered the patrician Belisarios to march out against them with some other members of the senate, Belisarios took every horse, including

${ }^{30}$ F. Curta, The Making of the Slavs. History and Archeology of the Lower Danube Region, c. 500-700, Cambridge 2001, pp. 45-46. 
those of the emperor, of the hippodrome, of religious establishments and from every ordinary man who had a horse. He armed his, troops arms led them out to the village of Chiton. Be shade an entrenched camp and began to capture same of the enemy and kill them. Next he ordered trees to be cut and dragged behind the army. The wind blew up a cloud of dust, which drifted over the barbarians, They, thinking that an enormous force was there, fled and went to the district of St Stratonikos at Dekaton. When they learned from scouts that a great garrison force was at the walls of Constantinople, they went to the region of Tzouroulon, Arkadioupolis and St Alexander of Zoupara and remained encamped there until holy Easter. After the feast of Easter, the emperor went out to Selymbria and everyone from the city went with him to rebuild the Long Wall where the barbarians had entered. The emperor remained there until August. Likewise the barbarians wandered about outside the city until August. Then the emperor ordered double-proved ships to be built to go to the Danube and oppose the barbarians as they crossed and make war on them, When the barbarians discovered this, they asked through an envoy to he allowed crossing the Danube safely. The emperor sent Justin, his nephew, the curopalates, to conduct them." 31

Syriac historians' general perception of the Slavs

The texts cited above, though being excerpts from only three Syriac historic works, can throw light on a general perception of the Slavs among the Syriac speaking Christians. From the information that these chronicles contain we can draw the conclusion that the Slavonian peoples were for them nothing more than another barbarian group invading the Roman Empire. The Slavs in the Syriac sources are mentioned almost everywhere in the context of war, invasion, plundering and things like that. That view was common also in the other Syriac chronicle, e.g., in Liber Chalipharum, compilation of various Syriac historical accounts, which was preserved in the eighth century manuscript, the Slavs were mentioned only once but as the invaders on Crete, "In the year 934 (A.D. 623) the Slavs invaded Crete and other isles. They enslaved there pious men from Qenneshrin and killed twenty of them." ${ }^{32}$

The picture of the Slav as a northern pagan barbarians whose incursions into the Empire and the sacrileges filled the Christians with fear, dominated the minds of the Syriac language users for centuries.

It is striking and worth stressing that the Christian writers of Syria and Mesopotamia never wrote about conversions of the Slavonian peoples into

${ }^{31}$ A Chronicle of John Malalas, a translation by E. Jeffreys, M. Jeffreys, R. Scott, Melbourne 1986, pp. 297-298. 18, 129.

32 "Anno 934 (A.D. 623) Slavi Cretam caeterasque insula invasere; atque illic pii viri Kenesrinenses comprehensi sunt, quorum fere viginti interfecti” (J. P. N. Land, Anecdota Syriaca, vol. 1, Lugduni Batavorum 1862, p. 115). 
Christianity. Even such ecclesiastical authorities and theologians as Michael the Great and Bar Hebraeus, who lived several centuries after the death of Constantine - Cyril and Methodius, the Apostles to the Slavs, seem to ignore their evangelisation work and omitted it totally in their chronicles.

\section{Apocrypha}

In the tenth chapter of the biblical book of Genesis the division of the land among Noah's sons was presented. For many years this description was treated as the basis of the Jewish and Christian ethnographic and linguistic typologies. One of the remnants of such a tradition is the terminology, used until now in area of linguistics (e.g., the Semitic, Chamitic and Cushite languages).

\section{Genealogies}

In the ancient genealogies, of course, the Slavonian peoples were not mentioned. The nations living in Central and Eastern Europe and known to the Roman and Greek Christian and Jewish authors as the Scythians and the Sarmatians were usually considered to be the descendants of Japheth. Such view was supported, e.g., by Josephus Flavius. ${ }^{33}$

The Judeo-Christian division of the land among Noah's sons was taken over by the Syriac authors. Like others they omitted the question of the Slavonian genealogy for a long time. In Ephrem's Commentary to Genesis only fifteen Japheth's tribes were mentioned, which supports totally the biblical text. However, in Cave of Treasures ( $6^{\text {th }}$ century) the number of peoples descending from Japheth arises up to thirty-seven and among them appears an intriguing one called "Asqolaye." ${ }^{34}$ It is difficult to say whether the Slaves were hidden under this name. There is some formal similarity with the term Sclavi or Sklaboi $(\Sigma \kappa \lambda \alpha \beta o \imath)$ as they were mentioned in the Greek and Latin sources. We must also take into consideration the possibility of corruption of the original name by copyists. Moreover, according to the author of Cave of Treasures, Asqolaye lived in the proximity of the Gelons, Avars and Atroqaye (Turcs?). The Avars' domination over the Slaves is very well documented and we know that the Slavonian tribes supported them in their raids into the Byzantine Empire. ${ }^{35}$ The Gelons were mentioned in Herodot's History (IV, 108-109). They lived in the area of present-day Ukraine, in the probable cradle of the Slavonian race. In the $6^{\text {th }}$ century the Turkic peoples were also present in Eastern Europe,

\footnotetext{
${ }^{33}$ In his Antiquitates (I, VI: I) the Scythians are called Magog's sons.

${ }^{34}$ W. Witakowski, The Division of the Earth between the Descendants of Noah in Syriac Tradition, "Aram" 5 (1993), p. 640.

${ }^{35}$ See, L. A. Tyszkiewicz, Stowianie i Awarowie, Wrocław 2009, pp. 19-34.
} 
which could support the presupposition that the term 'Asqolaye' is a corrupted form of Sklaboi/Sclavi.

Nevertheless, among the Syriac writers it was Michael the Great that transmitted the first reliable information about the Japheth's origin of the Slaves as he wrote in his chronicle, "Ils eurent les pays suivants : la contrée des Alains et des Turcs, et, à l'orient ; la Médie, l'Arménie, la Cappadoce, la Galatie, l'Asie, la Mœsie, la Thrace, l'Hellade et les pays qui sont au nord et à l'ouest de ceux-ci : la contrée des Grecs, des Romains, des Sarmates, des Slaves, des Kourgahe; à l'occident : le pays des Gaulois, l'Espagne et tous les autres qui se trouvent sur les confins de l'occident jusqu'à Gadira." ${ }^{36}$

A hundred years later this view was shared also by Bar Hebraeus, "And to the sons of JAPHET [came the inheritance], the whole of the north from east to west, the country of the ALANAYE, the TURKS, MEDIA, ARMENIA, CAPPADOCIA, GALATIA, ASIA, MYSIA, TARKI (THRACE?), ILADHA (HELLAS), the land of the GREEKS (IONIANS), the RHOMAYE (BYZANTINES), the SARMATIANS, the ASKLABHE (SCLAVS), the BULGARS, the GALLAYE, the SPANIARDS as far as GADIRA." 37

Summing up these data, we can come into conclusion that according to the Syriac authors the Slavs descended from Japhetic branch of peoples. Their abodes were located in the northeastern parts of the ancient oikoumene in the neighborhood of the Iranian Sarmatians and Turkic Bulgarians.

\section{The Slavs and the Syriac Acts of the Apostle Andrew attributed to St Ephrem}

Among the numerous versions of the Acts of the Apostle Andrew there exists a long Syriac metrical work containing the story of his travel to the land of human flesh eating dog-men. It was preserved in four manuscripts (the oldest of them, Vat. Syr. 117 , fol. 535-537, dates back to the $12^{\text {th }}$ century). ${ }^{38}$ The authorship of the work was attributed to St Ephrem.

The content of the Syriac Acts of Andrew reflects a common structure of the apocryphal works presenting the deeds of the Apostles. There is a motif of journey, cruel heathens, miracles, preaching and conversion. Nevertheless, the most interesting information that was mentioned in this poem is the name of the king of the dog-men. In line 192 we can read, wa rhet (w) mehda

${ }^{36}$ Chronique de Michel le Syrien, Patriarche Jacobite d'Antioche (1166-1199), op. cit., vol. 1, pp. 18-19.

${ }^{37}$ The Chronography of Gregory Abû'l Faraj, op. cit., p. 7 [Bedjan's edition: 8].

${ }^{38}$ The Acta were edited and translated into French by Michael van Esbroeck in: Actes syriaques d'André attributes à Éphrem, "Orientalia Christiana Analecta” 1998 (256), pp. 85-104. 
izzgadde șêd Būz malkā w'emar(w) leh. ${ }^{39}$ So the dog-men's king was called Būz (or Bōz) ${ }^{40}$ That was, however, also the name of Antes' king as Jordanes mentioned in his Getica, [Vinitharius, king of the Ostrogoths, S.B.] disliking remaining under the rule of the Huns, he withdrew a little from them and strove to show his courage by moving his forces against the country of the Antes. When he attacked them, he was beaten in the first encounter. Thereafter he did valiantly and, as a terrible example, crucified their king, named Boz, together with his sons and seventy nobles, and left their bodies hanging there to double the fear of those who had surrendered." ${ }^{41}$

Jordanes' version is the only information about the Antian king Boz. Could the Syriac author of the Acts mean the Slavonian Antes as he wrote about the dog-men that were ruled by Boz?

The dog-men (or dog headed men) were mentioned in numerous ancient sources. Ctesias writes that they lived in India. Herodotus (IV, 105) maintains that the Neurs, located in the area of present-day Ukraine, transformed into wolves once a year. Moreover, in the North they had the Cannibals as neighbors (IV, 100). In his History of Alexander the Great Pseudo-Callisthenes writes that the dog-men lived northward from the Caucasus mountains, beyond the abodes of the Hunns ${ }^{42}$ Similarly, in the seventh century the Syriac Apocalypse of Pseudo-Methodius, Cannibals ( $\bar{k} k l a y$ bnaynāše $\bar{e}$ ), who are called Dog of Man (kalb barnāš $\bar{a}$ ) are listed among 22 kingdoms enclosed beyond the northern Gate, built by Alexander the Great. ${ }^{43}$

The dog-men, then, were not the invention of the author of the Acts of Andrew. He could have based on the long tradition concerning those monstrous beings. Nevertheless, did he mean the Slavs when he wrote about them in his work?

The Slavonian Antes lived in the region northward from the Black Sea. That was the opinion of Jordanes, "The Antes, who are the bravest of these peoples dwelling in the curve of the sea of Pontus, spread from the Danaster to the Danaper, rivers that are many days' journey apart." 44

The Acts fail to provide a statement of the geographical localization of the dog-men's land (ar'ā dkalbē). It was only mentioned that Andrew should make his travel by ship. According to the Syriac History of Mar Mathew and Mar Andrew (the $10^{\text {th }}$ century), being a translation from Greek, the "City of Dogs"

39 "The heralds ran immediately to the king Boz and said to him."

${ }^{40}$ In the Vatican manuscript. In the later one there are also the forms: Būr and Pūd. See M. van Esbroeck, Actes syriaques d'André attributes à Éphrem, op. cit., p. 88.

${ }^{41}$ The Gothic History of Jordanes, op. cit., p. 121.

${ }^{42}$ The History of Alexander the Great, Being the Syriac Version of the Pseudo-Callisthenes, edited with an English translation and notes by E. A. Wallis Budge, Cambridge 1889, p. 152.

${ }^{43}$ W. Witakowski, The Division of the Earth between the Descendants of Noah in Syriac Tradition, "Aram" 5 (1993), p. 642.

${ }^{44}$ The Gothic History of Jordanes, op. cit., p. 60. 
was 'İrqā. ${ }^{45}$ The later term can be identified as Hyrcania, a land located at the southern shores of the Caspian Sea. Nevertheless, according to the oldest Christian tradition, the regions where the Apostle preached the Gospel were Greece, Pontus and Scythia, ${ }^{46}$ which embraced all lands northward from the Black See. Moreover, Nestor's Russian Primary Chronicle (the $12^{\text {th }}$ century) informs that Andrew came even to Russia, set up a cross on the hill at the Dnepr river in the site of today's Kiev and reached as far as Novogrod. ${ }^{47}$ This tradition was older than the $12^{\text {th }}$ century. ${ }^{48}$

As it has already been mentioned according to the Syriac History of Mar Mathew and Mar Andrew they preached in Hyrkania (Syr. 'İrqā). The name of this country, though of Greek provenience, was derived from the old-Iranian stem 'varka' (or 'vehrka'), meaning wolf. ${ }^{49}$ It can explain why the author of this work located the land of dogs there. Moreover, in the medieval Menologium of Basil II ( written about the year 1000 ) the land of St Andrew's mission is Bactria, the homeland of his Cynocephalic assistant. ${ }^{50}$ Thus the tradition of the eastern localization of Andrew's preaching is also attested.

The idea of dog-men itself seems to be connected with the primitive beliefs that man can transform into an animal. ${ }^{51}$ The ritual transformation of a young warrior into a wolf was widespread among the Indo-European and Turkic peoples. The latter considered themselves as descendants of the she-wolf. The phenomenon of lycanthropy was attested also among the Slavs. As early as in the sixth century Pseudo-Caesarius wrote about the Sclavenes that "call each other with the howl of wolves." ${ }^{2} 2$ The repercussion of these beliefs can be traced in the Slavonian lore, e.g., the werewolves. ${ }^{53}$ Thus calling the Slavs dog-men was not impossible for the Syriac authors.

Summing up, the name of king Buz, mentioned in the Acts of Andrew, could be derived from Jordanes' Getica. The author of the work probably used the popular traditions concerning this apostle and mixed them with his knowledge about the barbarian peoples of the North. It is possible that he knew some early

${ }^{45}$ The work was edited and translated by W. Wright in Apocryphal Acts of the Apostles. Edited from Syriac manuscripts in the British Museum and other libraries, London 1871, vol. 1: The Syriac texts, pp. 102-126, vol. 2: The English translations, pp. 93-115.

${ }^{46}$ Eusebius of Cesarea, Ecclesiatical History (III, 1).

${ }^{47}$ Apokryfy Nowego Testamentu, pod red. M. Starowieyskiego, vol. 2: Apostołowie; part 1: Andrzej, Jan, Pawel, Piotr, Tomasz, Kraków 2007, pp. 283-284.

${ }^{48}$ In Kiev, at the place, in which allegedly Andrew set up the cross, the church devoted to him was erected in 1086.

${ }^{49}$ Varkana or Vehrkana, see M. Eliade, Od Zalmoksisa do Czyngis-chana, Warszawa 2002, p. 8.

${ }^{50}$ D. G. White, Myths of the dog-men, Chicago 1991, p. 66.

${ }^{51}$ See M. Eliade, Od Zalmoksisa do Czyngis-chana, op. cit., pp. 7-24.

${ }^{52}$ F. Curta, The Making of the Slavs, op. cit., p. 325.

${ }^{53}$ A. Gieysztor, Mitologia Stowian, Warszawa 1982, p. 230-231. 
form of the tradition of Andrew's sojourn in Russia. Therefore, he could have connected it with the information about the Antes' king Boz and the lycanthropic customs of the Slavs. 